\title{
A TEORIA DO ERRO DE PROIBIÇÃO EM CLÁUDIO BRANDÃO
}

\section{CLAUDIO BRANDÃO'S THEORY ABOUT THE PROHIBITION ERROR}

\author{
Marco Aurélio Florêncio Filho ${ }^{1}$ \\ Mackenzie - SP
}

\section{Resumo}

Partindo-se do texto "Inconsciência de antijuridicidade: sua visão na dogmática penal e nos tribunais brasileiros", de Brandão, nomeadamente pela reconstrução do caminho teórico por ele proposto, desenvolve-se o tema central do erro, especificamente os parâmetros para a sua escusabilidade aplicados às suas espécies. Palavras-chave

Teoria do erro de proibição. Exclusão de Culpabilidade. Consciência de antijuridicidade. Claudio Brandão.

\section{Abstract}

Starting from the text "Anti-legality unconsciousness: its view on criminal dogmatics and Brazilian courts", by the reconstruction of the theoretical path he proposed, the central theme of the error develops, namely the parameters for its excusability applied to its species.

Keywords

Prohibition error theory. Exclusion of Guilt. Anti-legality awareness. Claudio Brandão.

1 Coordenador do Programa de Pos-Graduação da Faculdade de Direito da Universidade Presbiteriana Mackenzie. Presidente da Comissão de Direito Penal Econômico da OAB/SP. Doutor em Direito pela PUC/SP. Mestre em Direito pela Faculdade de Direito do Recife - UFPE. 


\section{Considerações iniciais}

Cláudio Brandão já alertava no início de seu texto que o erro, por ser um dos assuntos mais complexos e importantes da dogmática penal, deveria ter seu estudo mais detalhado e aprofundado pela doutrina ${ }^{2}$. Para iniciar o estudo sobre o instituto do erro é imprescindível conceituá-lo. Entretanto, antes de conceituar o que vem a ser erro no direito penal, deve-se registrar que em determinado ramo do direito não se distingue erro de ignorância, ou seja, o erro é tanto a falsa compreensão acerca de determinado objeto, quanto a sua falta de conhecimento. Se se tomar, entretanto, por base os ensinamentos da ontologia ${ }^{3}$, perceber-se-á que o erro é a falsa compreensão acerca de um determinado objeto, enquanto que a ignorância é a

2 BRANDÃO, Claudio. Inconsciência de antijuridicidade - sua visão na dogmática penal e nos tribunais brasileiros. Revista da Faculdade de Direito da Universidade de Lisboa. Vol XLI, N.1, Coimbra: Coimbra Editora. 2000, p.253.

3 “[...] ontologia é uma filosofia baseada na confiança no ser, parte do princípio de que alguma coisa 'é', que existe independentemente do nosso pensamento. Ela não se dirige à consciência, mas ao ser, que, em princípio, está indisponível e só está a disposição do homem na medida em que respeita leis implantadas no ser (na 'natureza'). Compreende-se que uma tal filosofia, que repousa na confiança no ser, que se oriente pela realidade objectiva, só seja possível numa época consistente em si mesma, alicerçada em fundamentos estáveis; que, sobretudo, também tenha confiança em si própria." KAUFMANN, A. e HASSEMER, W. Introdução à Filosofia do Direito e à Teoria do Direito Contemporâneas. Lisboa: Fundação Calouste Gulbenkian, 2002, p. 37-38. 
falta de conhecimento acerca de um objeto. No entanto, em sede de direito penal, enfatize-se, não se faz distinção entre erro e ignorância, visto que o conceito de erro abarca o de ignorância ${ }^{4}$. Segundo Luis Jiménez de Asúa,

En el área de la psicología hay una distinción fundamental entre a ignorancia y el error, que se halla ya en Platón. La

${ }^{4}$ Segundo Munhoz Netto, não há interesse para o direito penal em separar o erro da ignorância, visto que tanto o erro quanto a ignorância, em sua essência, constituem estados de desconformidade cognoscitiva. Logo, não existe óbice em unificar em um único conceito o erro e a ignorância, em âmbito, enfatize-se, de direito penal, visto que os efeitos que se referem ao erro e à ignorância são, também, os mesmos. MUNHOZ NETTO, Alcides. A ignorância da antijuridicidade em matéria penal. Rio de Janeiro: Forense, 1978, p. 03. Realizada a observação de que não há prejuízo, em matéria penal, em unificar os conceitos do erro e da ignorância, é importante mencionar que não se pode confundir a ignorância com a dúvida, pois quem tem dúvida, conhece, mesmo que tenuemente, algo. Nesse sentido, afirma Munhoz Netto, que "a ignorância não se confunde com a dúvida, porque aquela pressupõe a ausência de qualquer representação e, na dúvida, há mais de uma representação, uma as quais conforme à realidade. A dúvida também afasta-se do erro, porque a perplexidade ou incerteza entre as várias previsões que a caracterizam é incompatível com a formação de um convencimento em contraste com a realidade, que é da essência do erro. Ademais, ao contrário do que ocorre com o erro, a dúvida, enquanto tal, não vicia a vontade. Se o conflito de imagens é resolvido e o sujeito adquire o convencimento de estar na verdade, não estará mais em dúvida, embora possa incidir em erro; se não adquire tal persuasão, permanece em dúvida, não em erro; e agindo nesta situação psicológica, terá querido voluntariamente, ou por culpa, o próprio comportamento". MUNHOZ NETTO, Alcides. A ignorância da antijuridicidade em matéria penal. Rio de Janeiro: Forense, 1978, p. 04. 
primera supone la falta absoluta de toda representación y consiste en una entera ausencia de noción sobre un objeto determinado; es un sentido negativo. El error supone una idea falsa, una representación errónea de un objeto cierto; es un estado positivo (1945, p. 490-491)5.

Do conceito de erro infere-se que o conhecimento e o erro são dois institutos antagônicos, pois referidos estados psíquicos encontram-se em relação de exclusão lógica. Segundo Cirino dos Santos, "[...] o conhecimento exclui o erro e o erro indica desconhecimento sobre qualquer objeto"6

${ }^{5}$ ASÚA, Luis Jiménez. La ley e el delito: curso de dogmática penal. Caracas: Adreas Bello, 1945, p. 490-491. No mesmo sentido, afirma Fontán Balestra que "la distinta naturaleza de la ignorancia y el error radica en que la primera supone la ausencia absoluta de conocimiento respecto de determinada materia, en tanto que el error implica un conocimiento, que se tiene por verdadero o exacto, siendo falso. [...] La diferenciación carece de interés en la práctica, tanto porque es difícil imaginar un puro no saber en el que obra, como porque las legislaciones en general suelen equiparar los efectos jurídicos del error y la ignorancia. BALESTRA, Carlos Fontán. El elemento subjetivo del delito. Buenos Aires: Desalma, 1957, p. 142-143). Ainda no mesmo sentido NORONHA, Edgard Magalhães .Direito penal: introdução e parte geral. São Paulo: Saraiva, 1999, p.150.

${ }^{6}$ SANTOS, Juarez Cirino dos. A moderna teoria do fato punível. Curitiba: Fórum, 2004, p. 202. 
O estudo acerca do instituto do erro pode ser realizado tanto sob o ponto de vista da dogmática positivista (causalista), quanto do ponto de vista da dogmática finalista ${ }^{7}$. A teoria causalista da ação se utiliza da dicotomia do erro que remonta ao direito romano, erro de fato-erro de direito (error facti-errror ius), com tênues modificações ${ }^{8}$.

Sob o ponto de vista do pressuposto epistemológico finalista (dogmática finalista), modifica-se substancialmente a abordagem do instituto do erro. Nesse diapasão, a dicotomia passa a ser: erro de tipo-erro de proibição, e não mais erro de fato-erro de direito. A dicotomia finalista foi adotada pelo atual Código Penal brasileiro, em seus artigos 20 e 21, após a reforma da Parte Geral do Código de 1984.

O Erro de proibição é a falta de conhecimento acerca da ilicitude de um fato ou a sua falsa compreensão, ou seja, é o

${ }^{7} \mathrm{O}$ erro também pode ser estudado à luz da dogmática funcionalista, entretanto foge aos objetivos propostos na presente dissertação a análise de referida teoria.

8 "La primera teoría desarrollada en relación con el tratamiento del error en general está unida a la distinción entre el error de hecho y el error de Derecho así como con el principio de la ignorancia de la ley no excusa o el 'error iuris nocet'. Esta primera explicación hunde sus raíces en el Derecho romano y se impone en las siguientes etapas históricas hasta el desarrollo de la teoría del delito en la segunda mitad del siglo XIX.”. BARREALES, María A. Trapero. El error en las Causas de Justificación. Valencia: Tirant lo blanch, 2004, p. 48. 
DELICTAE, Vol. 5, No8, Jan..-Jun. $2020 \mid 73$

erro sobre a antijuridicidade do fato ${ }^{9}$. Há erro sobre a ilicitude do fato quando o agente não conhece a norma de proibição ${ }^{10}$ que diz

${ }^{9}$ Nesse sentido, afirma Jescheck que "el error de prohibición es la equivocación acerca de la antijuridicidad del hecho" JESCHECK, Hans-Heinrich, WEIGEND, Thomas. Tratado de derecho penal: parte general. Granada: Comares, 2002, p. 490. ${ }^{10}$ Norma de proibição ou norma proibitiva é a representação da valoração jurídica do ato realizada pelo agente. ZAFFARONI, Raúl Eugenio; Alejandro Slokar; e Alejandro Alagia. Manual de derecho penal: parte general. Buenos Aires: Editar, 2006, p. 57. Cláudio Brandão, ao fazer uma análise, sobre o gérmen da consciência de ilicitude, destaca que foram os gregos os primeiros a tratar de referido instituto. O autor baseia seu posicionamento na obra "As Leis" de Platão. Platão faz alusão a uma responsabilização penal diferenciada entre dois grupos: os cidadãos gregos e os estrangeiros e escravos. Os escravos e estrangeiros, por não terem sido educados conforme as leis do Estado, deveriam ter punição mais branda que os cidadãos gregos, por não conhecerem a ilicitude de suas condutas Inconsciência de antijuridicidade sua visão na dogmática penal e nos tribunais brasileiros. Revista da Faculdade de Direito da Universidade de Lisboa. Vol XLI, N.1. Coimbra: Coimbra Editora. 2000, p.279 e ss.. In casu, a incidência em erro funcionava como uma espécie de atenuante. Cláudio Brandão desenvolve sua linha de raciocínio a partir do seguinte trecho da obra "As Leis" de Platão, verbis: “(...) todo aquele que for pego roubando um templo, se for um estrangeiro ou um escravo, terá o estigma de sua maldição marcado a fogo na sua testa e nas suas mãos, além de sofrer o látego no número de golpes decretados pelos juízes; ademais, será expulso nu para além das fronteiras do país, pois talvez após ser assim punido, possa disciplinar-se para uma vida melhor. [...] mas se qualquer cidadão reiteradamente condenado por esse ato, ou seja, a perpetração de alguma falta gravíssima e infame contra os deuses, os pais ou o Estado, o juiz o considerará como já incurável, reconhecendo que, apesar de todo o treinamento e educação que recebeu desde a infância, não se conteve, a ponto de cometer pior das iniqüidades. Para ele a pena será a de morte, o que para os outros [cidadãos] será um exemplo benéfico, pois o verão caído em desgraça e eliminado para além das 
respeito ao fato, ou, conhecendo-a, tem-na por inválida, ou, ainda, em consequência de uma interpretação errônea, representa defeituosamente o seu âmbito de validade, considerando, em decorrência disso, o seu comportamento como juridicamente admissível. ${ }^{11}$

Nessa toada, a forma normal de erro de proibição será desconhecer a norma penal. Sobre a citada norma penal, Brandão afirmou que ela, que é um imperativo - porquanto é um mandamento positivou ou negativo de comportamento - é compreendida a partir do tipo, mas não se confunde com ele. In verbis.

"O tipo permite ver através dele a norma, que é um imperativo de comportamento, positivo ou negativo, mas esse imperativo existe de maneira logicamente autônoma ao próprio tipo. Para exemplificar, tomemos um crime comissivo e um crime omissivo. $\mathrm{Na}$ lesão corporal (art. 129 do Código Penal), o tipo é "ofender a integridade corporal ou a saúde de outrem", mas a norma que se extrai dele é: não se deve

fronteiras do país." PLATÃO. As leis, ou da legislação e epinomis. São Paulo: Edipro, 1999, p. 358-359.

${ }^{11}$ SERRA, Tereza. Problemática do erro sobre a ilicitude. Coimbra: Almedina, 1991, p. 67. 
realizar ofensas a integridade corporal ou à saúde de outrem; no delito de omissão de notificação de doença (art. 269 do Código Penal), o tipo estabelece "deixar o médico de denunciar à autoridade pública doença de notificação compulsória”, mas a norma que se extrai deste tipo é: deve o médico efetuar a comunicação à autoridade pública de toda doença de notificação compulsória. Assim, a norma decorre do tipo como um imperativo positivo ou negativo, mas não se confunde com ele"12

$\mathrm{O}$ autor, quando incide em erro de proibição, tem a consciência atual e a vontade de realizar os elementos contidos no tipo, logo o dolo resta-se perfeito. O sujeito, entretanto, não tem o conhecimento sobre a reprovação de sua conduta ou faz uma má interpretação sobre a reprovabilidade de seu comportamento, afastando, assim, a culpabilidade, por falta de

${ }^{12}$ BRANDÃO, Cláudio. Bem jurídico e norma penal: a função da antinormatividade na teoria do crime. DELICTAE: Revista de Estudos Interdisciplinares sobre o Delito, v. 3, n. 4, p. 07-45, jul. 2018. ISSN 2526-5180. Disponível em: <http://www.delictae.com.br/index.php/revista/article/view/61>. doi: https://doi.org/10.24861/2526-5180.v3i4.61, p. 31-32. 
consciência de antijuridicidade, que, como se sabe, para os finalistas, é elemento autônomo dentro do juízo de culpabilidade.

O erro de proibição diferencia-se do erro de tipo porque, nesse último, o agente crê que está a realizar uma ação diversa da que pratica. Ainda, deve-se ressaltar que o erro de tipo exclui diretamente o injusto (ao menos o injusto doloso, visto que, nos crimes em que existe a previsão da modalidade culposa, o agente poderá ser responsabilizado, se não observou o dever jurídico de cuidado), enquanto que o erro de proibição afastará a culpabilidade quando inevitável, sem ter relação com a tipicidade. $\mathrm{O}$ erro de proibição somente afeta a reprovabilidade do injusto. Assim, o único efeito de um erro de proibição vencível é produzir uma menor reprovação ${ }^{13}$.

A consciência de antijuridicidade não se identifica com o conhecimento do tipo legal, mas sim com a reprovabilidade da conduta, vista através do espelho do tipo, isto é da norma penal. Essa noção da consciência de antijuridicidade é extraída do seu conceito material.

É irrelevante para que haja a configuração da consciência de ilicitude, o conhecimento do tipo legal. Deve-se

${ }^{13}$ ZAFFARONI, Raúl Eugenio; Alejandro Slokar; e Alejandro Alagia. Manual de derecho penal: parte general. Buenos Aires: Editar, 2006, p. 568-569. 
observar, sim, se o agente conhecia a anti-socialidade da conduta $^{14}$. Nesse sentido afirma Welzel,

El objeto de la conciencia del injusto y del error de prohibición es la antijuridicidad de la conducta (planeada). El autor tiene que poder ser consciente de la contradicción de su conducta con el orden de la comunidad, sobre el que descansa la prohibición penal y puesto de manifiesto por ésta. No es necesario, sin embargo, que el autor conozca o pudiera conocer el concepto jurídico mismo (luego, la ley penal), o incluso la conminación de pena. Por el contrario, no es suficiente que el autor pudiera ser consciente de la mera inmoralidad de su conducta. El extranjero en cuya patria no es antijurídica la homosexualidad simple, sabe, sin duda, que sus acciones homosexuales inmorales, pero por ello no sabe todavía que la ejecución de tales acciones en Alemania es considerada como infracción inadmisible del orden

${ }^{14}$ BRANDÃO, Cláudio. Teoria jurídica do crime. Rio de Janeiro: Forense, 2002, p. 151. 
comunitario. Se encuentra, pe eso, en error de prohibición ${ }^{15}$.

Essa análise feita acerca da "anti-socialidade" da ação, para que se constitua a consciência de antijuridicidade, é bastante importante para o direito penal, pois tem o escopo de minimizar as consequências do vetusto princípio de que todos devem ter conhecimento da lei penal (error jus nocet).

Há de se mencionar que erro de direito e erro de proibição são dois institutos distintos. Isto se dá porque o primeiro tem por objeto a lei, enquanto o segundo tem por objeto a antijuridicidade do fato. Explique-se. Incide em erro de direito quem não tem conhecimento da lei ou a compreende mal, enquanto incide em erro de proibição quem não tem conhecimento sobre o caráter ilícito de sua conduta, ou tem a sua falsa compreensão.

A ideia de antijuridicidade é formada pelos valores de uma sociedade, isto é, a ideia de ilicitude se constitui a partir da sociedade em que se encontra inserido o autor da conduta.

A consciência de ilicitude pode ser analisada sob dois ângulos. O primeiro é o da presença da consciência de antijuridicidade na mente do sujeito, ensejando assim a

15 WELZEL, Hans. Derecho penal alemán: parte general. Santiago: Editorial Juridica de Chile, 1997, p. 202. 
reprovação penal. O segundo ângulo de estudo é justamente a ausência da consciência de ilicitude na mente do sujeito, dando origem ao erro de proibição. ${ }^{16}$

É certo que a antijuridicidade é um juízo de valor negativo, ou desvalor, que qualifica a conduta como contrária ao direito. Esse juízo de valor negativo sobre a conduta é formado, justamente, porque a conduta realizada pelo autor não é uma conduta esperada pelo ordenamento jurídico, por isso a conduta é considerada reprovável.

Para se alcançar, então, a potencial consciência da ilicitude, o autor, a partir dos conceitos extraídos da sociedade em que se encontra, busca criar o conceito de "anti-socialidade" da conduta.

A "anti-socialidade" da conduta, nessa toada, é alcançada através da valoração paralela na esfera do profano. Para Mezger a consciência de proibição de uma conduta é obtida através dos conceitos retirados pelo autor da sociedade onde ele se encontra inserido, da cultura dessa sociedade ${ }^{17}$.

${ }^{16}$ BRANDÃO, Claudio. Inconsciência de antijuridicidade - sua visão na dogmática penal e nos tribunais brasileiros. Revista da Faculdade de Direito da Universidade de Lisboa. Vol XLI, N.1, Coimbra: Coimbra Editora. 2000, p.272.

${ }^{17}$ MEZGER, Edmund. Derecho penal: parte general, libro de estudios. Buenos Aires: Editorial Bibliográfica Argentina, 1955, p. 247-255. E, ainda, MEZGER, Edmund. Tratado de derecho penal. Tomo II. Madrid: Revista de Derecho Privado, 1949, p. 163-164. 
Além dos conceitos absorvidos da sociedade em que se encontra inserido, o agente retira do seu próprio interior essa noção, são as denominadas valorações de cunho interno para a formação da "anti-socialidade". A isso se chama valoração paralela na esfera do profano, porque será considerada reprovável, pelo autor, toda conduta que possa ser também reprovável pelos sistemas extra-jurídicos que regulam a conduta humana (usos sociais, religião, moral etc.) ${ }^{18}$.

Há, assim, uma análise interna e externa para que se perfaça a consciência de ilicitude.

Apesar de não aceitarmos a teoria de Mezger para a determinação da anti-socialidade da conduta ${ }^{19}$, é certo que os autores finalistas que adotam a teoria da "valoração paralela na esfera do profano", certamente não aceitam o posicionamento da consciência de ilicitude como elemento integrante do dolo, como os causalistas.

Assim, não se adota, no presente trabalho, o pressuposto epistemológico causalista da ação, adotado por

${ }^{18}$ Nesse sentido, afirma Cláudio Brandão que "a valoração paralela do autor, acerca da consciência da antijuridicidade na esfera do profano, significa uma apreciação da mesma com relação aos pensamentos da pessoa individual e no ambiente do autor, que marche na mesma direção e sentido da valoração legal-judicial” BRANDÃO, Cláudio. Teoria jurídica do crime. Rio de Janeiro: Forense, 2002, p. 155.

${ }^{19}$ Isto porque preferimos uma composição polifônica da consciência de ilicitude, afeta à analise cultural do indivíduo e forjada pela teoria da linguagem. 
Mezger, pois, como se sabe, com o finalismo, o dolo e a culpa foram deslocados do juízo de culpabilidade para o juízo de tipicidade, dando ao dolo um caráter puramente naturalístico, evitando que se exija no dolo uma potencial consciência da ilicitude do fato.

O dolo, ao ser deslocado para o juízo de tipicidade, permitiu à culpabilidade uma composição eminentemente normativa, ao ser formada pela consciência de ilicitude (agora separada do dolo); imputabilidade; e exigibilidade de conduta conforme o direito. Por isso, os finalistas são conhecidos pela criação da teoria normativa pura da culpabilidade.

O dolo, assim, deixa de ser um elemento normativo, ao lado da consciência de antijuridicidade (antigo dolus malus), e passa a ser um elemento psíquico (naturalístico), localizado na tipicidade. Ademais, cabe mencionar que a consciência existente no dolo, a partir dos finalistas, é uma consciência atual e naturalística.

A identificação da consciência de antijuridicidade com a consciência da lei deve ser desde já rechaçada. Observe as lições de Brandão sobre o assunto,

A presunção de conhecimento de lei é uma das maiores mentiras do ordenamento jurídico! Se, no meio de dezenas de milhares de leis, nem mesmo os operadores do Direito sabem-nas todas, que se dirá, 
portanto, dos indivíduos estranhos ao ambiente jurídico. Portanto, a consciência da antijuridicidade não pode se basear nela. Como se pode conceber censurar o autor de um fato típico e antijurídico com base em uma ilusão? ${ }^{20}$

Ademais, como aponta Brandão, como antijuridicidade e lei são objetos diversos, consciência de antijuridicidade não pode ser identificada como consciência da lei por um óbice trazido pela teoria do conhecimento ${ }^{21}$

A solução que a dogmática alemã deu, destarte, ao vetusto princípio da ignorantia legis non excusat, foi formular o conceito de consciência de antijuridicidade material, e, assim, retirar a responsabilidade penal do sujeito que desconhece o caráter ilícito de sua conduta, sem fazer correspondência com o desconhecimento de lei, antijuridicidade formal.

A consciência de ilicitude passa a não mais se identificar com o conhecimento da lei, como era identificada

${ }^{20}$ BRANDÃO, Claudio. Inconsciência de antijuridicidade - sua visão na dogmática penal e nos tribunais brasileiros. Revista da Faculdade de Direito da Universidade de Lisboa. Vol XLI, N.1, Coimbra: Coimbra Editora. 2000, p.274.

${ }^{21}$ BRANDÃO, Cláudio. Culpabilidade: sua visão na dogmática penal e nos tribunais brasileiros. Revista portuguesa de ciência criminal. Ano 15. N.2. Coimbra: Coimbra editora. 2005. P.225 e ss. 
antes dos estudos de Graf zu Dohna, desenvolvidos, decerto, pelos finalistas. Segundo Munhoz Netto,

distingue-se a ignorância da antijuridicidade, da ignorância da lei. Essa distinção é útil para impedir que o princípio político do error iuris conduza à punição de condutas inculpáveis. A diferença reside em que a ignorância da lei é o desconhecimento dos dispositivos legislados, ao passo que ignorância da antijuridicidade é o desconhecimento de que a ação é contrária ao direito. Por ignorar a lei, pode o autor desconhecer a classificação jurídica, a quantidade da pena ou as condições de sua aplicabilidade, possuindo, contudo, representação da ilicitude do comportamento. Por ignorar a antijuridicidade, falta-lhe tal representação ${ }^{22}$.

A construção de um conceito de antijuridicidade material, consoante os pressupostos da teoria da valoração

${ }^{22}$ MUNHOZ NETTO, Alcides. A ignorância da antijuridicidade em matéria penal. Rio de Janeiro: Forense, 1978, p. 20. 
paralela na esfera do profano, foi um grande passo que a dogmática alemã galgou.

Entretanto, verifica-se, ainda, o princípio do error ius nocet no direito penal brasileiro, presente na primeira parte do artigo 21, do Código Penal brasileiro, ao afirmar que "o desconhecimento de lei é inescusável”. Ora, esse princípio de política legislativa, que prevê a presunção absoluta das leis por todos os cidadãos, não pode prosperar nos moldes de um direito penal da culpabilidade, que tem por base a análise do agente, porque, segundo referido princípio, todos devem conhecer a lei, ou seja, se presume que o agente tenha conhecimento de todas as leis, quando, em verdade, nem mesmo os juristas conhecem as conhecem. Segundo Zaffaroni,

El principio de culpabilidad y su violación mediante la regla error juris nocet expresan la dialéctica entre estado de derecho y estado de policía en la teoría del error. A favor de la regla error juris nocet se argumentaba que las prohibiciones penales eran obvias para todos. Esto no es sostenible frente a actual legislación penal, que ya no es un limitado catálogo de conductas más o menos conocidas por todos, sino un abigarrado conjunto de disposiciones si transparencia. De la vieja ilusión iluminista 
de una ley penal tan clara que cualquiera pudiese conocerla, se ha pasado a una situación en que la ley no es conocida por casi nadie e incluso quines la interpretan técnicamente tienen grandes dificultades ${ }^{23}$.

Nesse sentido, não se pode exigir a presunção do conhecimento absoluto das leis penais por todos os cidadãos, pois, atualmente, vive-se um momento de "inflação legislativa", impossibilitando o conhecimento da existência das leis em vigor, até para os juristas.

Além da grande quantidade de leis existentes no país, deve-se ressaltar a complexidade de muitas dessas leis, dificultando ainda mais sua compreensão.

Quem não sabe que sua ação se encontra reduzida em um tipo penal, não pode compreender o caráter ilícito de sua conduta. A exigência da lei prévia tem o escopo de fazer com que os cidadãos possam conhecer e compreender o caráter ilícito da ação penal reduzida em um tipo. O princípio da culpabilidade, assim, como necessária conseqüência da legalidade, faz com que

${ }^{23}$ ZAFFARONI, Raúl Eugenio; Alejandro Slokar; e Alejandro Alagia. Manual de derecho penal: parte general. Buenos Aires: Editar, 2006, p. 567-568. 
o poder punitivo Estatal não possa agir quando não exista o conhecimento e a compreensão, pelo cidadão, da norma penal ${ }^{24}$.

Nesse diapasão, não há mais como se sustentar, com base nos princípios de um Estado Democrático de Direito, o princípio do error ius nocet, visto que referido princípio viola os princípios constitucionais da legalidade e da culpabilidade.

Segundo Cirino dos Santos,

Se o Direito Penal do Estado Democrático de Direito assenta no princípio da legalidade, expresso na fórmula nullum crimen sine lege, que fundamenta a incriminação de condutas, e no princípio da culpabilidade, expresso na fórmula nullum crimen sine culpa, que fundamenta a responsabilidade e a criminalização individual, então a lei ordinária não pode, em nenhuma hipótese, contrariar esses princípio - e, portanto, o princípio $d a$ culpabilidade não pode ser cancelado para garantir a eficácia da lei penal, como pretende um setor da literatura penal. Não é o princípio da culpabilidade que deve se

${ }^{24}$ ZAFFARONI, Raúl Eugenio; Alejandro Slokar; e Alejandro Alagia. Manual de derecho penal: parte general. Buenos Aires: Editar, 2006, p. 567. 
adequar à lei, mas a lei que deve se adequar ao princípio da culpabilidade, sob quaisquer critérios de interpretação ${ }^{25}$.

A culpabilidade frente o direito penal tem um papel importantíssimo, visto que a forma de se debruçar sobre a culpabilidade indica o direito penal de cada época e Estado. É sabido, pois, que quanto mais se aperfeiçoa e enriquece a noção de culpabilidade, a utilização da pena se demonstra cada vez menor ${ }^{26}$.

Assim, parece nítida a inconstitucionalidade da primeira parte, do artigo 21, do Código Penal brasileiro, por violar frontalmente os princípios constitucionais da legalidade e da culpabilidade.

Há várias espécies de erro de proibição ${ }^{27}$, segundo o pressuposto epistemológico finalista da ação. A partir deste

${ }^{25}$ SANTOS, Juarez Cirino dos. A moderna teoria do fato punível. Curitiba: Fórum, 2004, p. 237-238.

${ }^{26}$ TOLEDO, Francisco de Assis. Princípios básicos de direito penal. São Paulo: Saraiva, 1982, p. 58.

27 Segundo Espinar, "la doctrina y la Jurisprudencia distinguen diversas clases de error de prohibición: el error de prohibición directo y el error de prohibición indirecto; tanto uno como otro pueden ser, a su vez, vencible e invencible ESPINAR, José M. Zugaldía. Delitos de acción. La culpabilidad (I). In: ESPINAR, José M. Zugaldía; ALONSO, Esteban J. Pérez. Derecho penal: parte general. Valencia: Tirant lo blanch, 2002, p. 632. 
DELICTAE, Vol. 5, No 8 , Jan..-Jun. $2020 \mid 88$

momento, tratar-se-á dessas espécies com o intuito de tornar mais claro o instituto do erro de proibição.

\section{2. (In)escusabilidade do erro de proibição}

A consciência de ilicitude, a exigibilidade de conduta diversa e a imputabilidade são elementos que compõem o juízo de culpabilidade. Por serem referidos elementos normativos, o juízo de culpabilidade passou a ser um juízo eminentemente normativo ${ }^{28}$.

Também, pode-se perceber que o juízo de culpabilidade $^{29}$, conforme o pressuposto epistemológico finalista

${ }^{28}$ A teoria finalista da ação foi responsável pela elaboração da teoria normativa pura da culpabilidade, visto que deslocou o dolo e a culpa que se encontravam alocados na culpabilidade (conforme a teoria causalista da ação), para a tipicidade, deixando na culpabilidade apenas elementos normativos.

${ }^{29}$ A culpabilidade é um juízo de reprovação pessoal feito ao autor de um fato típico e antijurídico, porque podendo se comportar conforme o ordenamento jurídico, optou, livremente, por se comportar contrário ao ordenamento jurídico. Nesse sentido, afirma Córdoba Roda que, “[...] la culpabilidad aparece concebida, según una formulación ampliamente difundida, como un juicio de reproche personal que se dirige al sujeto por la razón de que, no obstante poder cumplir las normas jurídicas, llevó a cabo una acción constitutiva de un tipo penal; es decir, en atención a que realizó una conducta prevista como delito pese a que estaba en situación de actuar de modo distinto. La culpabilidad aparece, pues, entendida como un juicio de reproche cuyo presupuesto es el poder del sujeto de adaptar su conducta a las normas del Derecho" CÓRDOBA RODA, Juan. Una nueva concepción de delito: la doctrina finalística. Barcelona: Ariel, 1977, p. 23. 
da ação, é um juízo que se volta em torno do autor do fato, sobre o sujeito da ação, diferentemente dos juízos de tipicidade ${ }^{30}$ e antijuridicidade ${ }^{31}$, que são juízos que se voltam em torno do fato. A culpabilidade, por ser, assim, o último requisito para se constituir formalmente um delito, será, por conseguinte,

${ }^{30}$ A Tipicidade é um juízo de adequação do fato ao tipo legal do ordenamento jurídico penal. Brandão assim a definiu: "relação de correspondência que se verifica entre uma ação que se deu historicamente no espaço e no tempo e a imagem conceitual expressada, sob ameaça de uma pena, em uma lei”. BRANDÃO, Claudio. Tipicidade penal: dos elementos da dogmática ao giro conceitual do método entimemático. Coimbra:Almedina. 2012, p.34.

${ }^{31}$ A Antijuridicidade é um juízo de valor negativo, ou desvalor, que qualifica o fato como contrário ao ordenamento jurídico penal. BRANDÃO sobre ela escreveu que "Tanto à antijuricidade quanto a tipicidade são juízos sobre o mesmo objeto: a conduta. Cabe à primeira a censura do comportamento, ocorrido através da qualificação que se lhe é atribuída em face da sua contrariedade com o direito. (...) Apesar de aparentemente paradoxal, a antijuridicidade não é uma teoria do contrário ao direito, mas é uma teoria do conforme o direito. Maurach, neste espeque, faz a seguinte afirmação, 'a teoria da antijuridicidade é, na prática, uma teoria do conforme o direito, a saber, a apresentação daquelas condutas que, apesar do cumprimento do tipo, são no caso particular, não antijurídicas' (...) A antijuridicidade está definida nos códigos penais negativamente, isto é, a partir das suas cláusulas de exclusão. O código penal brasileiro não é exceção a esta afirmação, veja-se o disposto no art. 23." BRANDÃO, Claudio. Tipicidade penal: dos elementos da dogmática ao giro conceitual do método entimemático. Coimbra:Almedina. 2012, p.149 e ss. 
pressuposto à aplicação da pena. Se não houver culpabilidade, não há que se falar em pena ${ }^{32}$.

Com acerto, não se pode falar em pena se não houver a consciência de antijuridicidade do agente. Essa é uma garantia de um direito penal que se volta para a pessoa humana.

Se o erro de proibição exclui a culpabilidade, então se diz que o erro de proibição é escusável, ou invencível. Não há um critério rígido para se determinar a escusabilidade do erro de proibição, visto que em cada caso concreto cabe ao juiz decidir se o sujeito possuía, ou não, consciência de ilicitude e, caso o autor não tivesse referida consciência, se era possível adquiri-la (daí a consciência de ilicitude não ser atual, mas sim potencial). Segundo Cláudio Brandão,

Sabe-se que um crime, como fato particular e humano, jamais terá outro idêntico. Por

32 Brandão aponta que as raízes da vinculação da pena à culpa são mais antigas que o direito penal científico, estado descritas no pensamento de Francisco de Vitória. BRANDÃO, Claudio; HOMEM, Pedro Barbas. Do direito natural aos direitos humanos. Coimbra:Almedina. 2015, p.341 e ss. Em outro trabalho, Brandão acentua que as razões da pena estão fundamentadas no próprio homem e a culpabilidade é o elemento que o reprova. BRANDÃO, Claudio. Tobias Barreto e pena criminal. Revista de Estudos Criminais. Ano XI, N.50, São Paulo:Síntese. 2013, p. 129. Sobre a obra de Vitória, consulte-se o artigo BRANDÃO, Claudio. THE ROOTS OF HUMAN RIGHTS: THE EPISTEMOLOGICAL TURN PROVOKED BY FRANCISCO DE VITÓRIA. HUMANITIES AND RIGHTS GLOBAL NETWORK JOURNAL, 1(1), 720. 2019. https://doi.org/10.24861/2675-1038.v1i1.9 
isso não é possível fixar a exata linha divisória entre o erro escusável e o inescusável e o inescusável, devendo apenas fixar-se linhas gerais. Ela, com efeito, deve permanecer numa zona nebulosa. O erro será escusável na exata medida que deva ficar excluído o juízo de culpabilidade ${ }^{33}$.

Diferentemente do erro de proibição escusável (invencível), o erro de proibição inescusável (vencível) não elimina a responsabilidade do agente, ou seja, sua reprovação.

$\mathrm{O}$ órgão julgador deve ser cauteloso ao analisar a consciência de antijuridicidade do agente, que deve ser analisada em sua plenitude, ou seja, deve ser investigada em todos os fatos que constituem a vida do agente, isto é, os preceitos costumeiros, morais, religiosos, sociais, em suma, todos os elementos formadores da convicção do agente.

Destaca Zaffaroni que, por muito tempo, se sustentou que o erro de proibição inescusável (vencível) violava o "dever de informação jurídica”, entretanto o certo é que este dever "geral" não existe, e, destaca referido autor, se existisse, seria importante perguntar o que acontece quando se ignora este

${ }^{33}$ BRANDÃO, Cláudio. Teoria jurídica do crime. Rio de Janeiro: Forense, 2002, p. 210. 
dever? Ou melhor, como se alcançar este dever geral de informação? Em verdade, a vencibilidade ou invencibilidade do erro de proibição é um "limite da culpabilidade", ou seja, um limite de exigibilidade e, por conseguinte, de reprovabilidade da conduta $^{34}$.

Atualmente, é pacífico entre os doutrinadores reconhecer que o erro de proibição, invencível (escusável) afasta a culpabilidade, e, em decorrência, afasta a responsabilidade criminal do agente ${ }^{35}$.

Referido entendimento já se encontra disposto em nosso Código Penal brasileiro, desde a reforma de 1984, com a instituição do erro de proibição, previsto no artigo 21.

O erro de proibição inescusável, diferentemente do erro de proibição escusável, parte do pressuposto de que o agente não conhece a ilicitude do fato, todavia teria condições de se informar sobre ela, suscitando assim maiores dúvidas.

34 ZAFFARONI, Raúl Eugenio; Alejandro Slokar; e Alejandro Alagia. Manual de derecho penal: parte general. Buenos Aires: Editar, 2006, p. 569.

35 Segundo Stratenwerth, "a) Durante mucho tiempo el tratamiento del error de prohibición fue extraordinariamente discutido. De todos modos - como lo explicamos al comienzo -, en los años posteriores a la guerra hubo unidad con respecto a que el error de prohibición inevitable que le quita al autor la posibilidad de conducirse según lo establecido por el deber, tiene efecto de excluir la culpabilidad, o sea, de determinar la impunidad.” STRATENWERTH, Günter. Derecho penal: parte geral. Caracas: Editoriales de Derecho Reunidas, 1982, p. 183. 
O erro de proibição vencível (inescusável) deve ser analisado a partir do caso concreto e não a partir de normas abstratas, ou seja, cabe ao juiz, e daí a cautela, analisar se poderia o agente alcançar a consciência de que a ação praticada era reprovável pelo ordenamento jurídico.

Segundo Bitencourt, "em razão de sua atividade, o agente está obrigado a, antes da realização de determinadas condutas, informar-se a respeito da licitude ou ilicitude"36. Entretanto, permanece a pergunta: qual deve ser o critério para se alcançar essa referida informação?

Segundo Zaffaroni, a evitabilidade da compreensão da criminalidade da conduta deve se valorar sempre em relação ao sujeito concreto e suas circunstâncias, o que permite afirmar que devem estar presentes, pelo menos, três aspectos que são imprescindíveis para a sua correta valoração: 1) se foi possível se valer de algum meio idôneo de informação; 2) se a urgência na tomada da decisão lhe impediu de se informar ou refletir sobre a conduta; e 3) se era exigível imaginar a criminalidade de sua conduta, o que não acontece quando, conforme sua capacidade intelectual, sua instrução ou treinamento, não tivesse motivos para a presumi-la ${ }^{37}$.

36 BITENCOURT. Cezar Roberto. Erro de tipo e erro de proibição: uma análise comparativa. São Paulo: Saraiva, 2003, p. 115.

37 "Como cualquier limite de culpabilidad o reproche, la vencibilidad del error debe determinarse conforme a las condiciones personales del agente y nunca en función 
Um exemplo de erro de proibição inescusável elucidará o assunto. Considere que um cidadão inglês veio passar férias no Brasil e aluga um veículo automotor para conhecer as praias do litoral pernambucano. Sem se informar sobre as normas de trânsito do Brasil, termina por provocar um acidente em uma ultrapassagem, pois terminou por ultrapassar pela faixa da direita, atingindo um transeunte que trafegava pelo acostamento, causando-lhe a morte.

de una pretendida objetividad que acuda a una figura de imaginación (un homúnculo jurídico u hombre normal). Siempre se reprocha a una persona concreta, en situación y circunstancias también concretas. Si bien el código argentino no contiene una fórmula general de la imputabilidad o culpabilidad disminuida, no significa que no reconozca grados de reprochabilidad conforme a la capacidad psíquica de la persona. Se trata de una dato de realizad que la ley no puede desconocer ni alterar. La capacidad de imaginación, el juicio crítico, el nivel de pensamiento abstracto, de atención, de fijación mnémica, de sensopercepción, etc., son funciones que pueden estar disminuida de modo que hagan inexigible que el agente imagine la criminalidad de su acción, que la deduzca por un análisis reflexivo de los datos disponibles, que comprenda su lesividad, etc. Por ello, el error exculpante y la imputabilidad no son conceptos que deban separarse completamente, sino que el grado de capacidad psíquica de culpabilidad puede incidir en la invencibilidad del error. En otras palabras: es posible que haya personas que no sean incapaces psíquicos de culpabilidad respecto de ese injusto en concreto, pero que, por sus características psíquicas, sea imposible exigirles, en la concreta circunstancia del hecho, que hayan vencido o evitado el error ZAFFARONI, Raúl Eugenio; Alejandro Slokar; e Alejandro Alagia. Manual de derecho penal: parte general. Buenos Aires: Editar, 2006, p. 571. 
Para se analisar a potencial consciência de ilicitude do agente, faz-se necessário analisar os três pontos destacados por Zaffaroni, caso o agente se enquadre nos três, incidirá em erro de proibição inescusável, e será punido no limite de sua culpabilidade, consoante o disposto no artigo 21, do Código Penal brasileiro, in fine.

É importante destacar que a expressão "poderá diminuí-la" prevista no artigo 21, do Código Penal, in fine, deve ser interpretada como "deverá diminuí-la", visto que o agente deve ser punido no limite de sua culpabilidade, conforme os ditames de um direito penal moderno.

Assim, quem desconhecia a natureza ilícita da conduta não pode ser punido como se a conhecesse. A redução da pena deve ser, pois, obrigatória, e não discricionária, ficando o magistrado obrigado a sempre aplicá-la.

Caso o artigo 21 do Código Penal não seja interpretado no sentido da obrigatoriedade da redução de pena, o que seria uma afronta ao direito penal da culpabilidade, cabe fazer alusão ao que dispõe o artigo 59 do Código Penal brasileiro, que obriga o magistrado observar a culpabilidade do agente antes de imputar a pena ${ }^{38}$.

38 O artigo 59 do Código Penal não tem influência da dogmática alemã, mas sim possui nítida influência do positivismo criminológico italiano. Não é esse o cunho que se quer dar ao presente trabalho, visto que se tenta aqui construir uma teoria do erro com base numa dogmática penal, mesmo reconhecendo os limites que a 
Bitencourt faz menção à observância do art. 59 do Código Penal, quanto à cominação de uma pena sobre os casos de erro de proibição inescusável. Segundo o referido autor,

[...] não se pode ignorar que a responsabilidade decorrente do descuido em conhecer a lei não é a mesma e nem tem o mesmo grau da responsabilidade de uma consciente desobediência à lei conhecida. Mas essa diferença de gradação da maior ou menor censurabilidade será objeto da medição da pena, nos termos do artigo 59 do $\mathrm{CP}^{39}$.

Não se concorda com o referido autor, pois se entende que essa análise não deve ser realizada com base no artigo 59 do Código Penal, mas sim no próprio artigo 21, in fine, sendo o juiz

dogmática esbarra. Também, não se pode esquecer que todo conceito jurídico-penal é um conceito político. No entanto, a proposta do presente trabalho é dogmática. No caso em análise, uma interpretação dogmática em torno do art. 21 do CP, já soluciona o problema da redução de pena, visto que a pena deve ter por base e limite a culpabilidade do agente.

39 BITENCOURT. Cezar Roberto. Erro de tipo e erro de proibição: uma análise comparativa. São Paulo: Saraiva, 2003, p. 115. 
obrigado a reduzir a pena, nos casos de incidência em erro por parte do agente.

\section{Espécies de erro de proibição \\ 3.1 Erro de proibição direto}

Há erro de proibição direto quando o agente não compreende uma norma proibitiva ou faz uma má-interpretação sobre o seu respeito. Norma proibitiva não está aqui empregada no sentido de lei, mas de antijuridicidade ${ }^{40}$.

Segundo Brandão,

"É pelo erro de proibição que extraímos a relação entre antinormatividade e culpabilidade. A espécie normal dessa dirimente - o erro de proibição direto - não

40 BRANDÃO, Cláudio. Teoria jurídica do crime. Rio de Janeiro: Forense, 2002, p. 204. Há erro sobre a proibição jurídica como tal quando o autor não reconhece a norma de proibição diretamente referente ao fato, tem-na por não-válida ou, em conseqüência a errada interpretação, chega a falsas representações de seu âmbito de validade e por este fundamento considera sua conduta como juridicamente admissível (= erro de proibição direto) WESSELS, Johannes. Direito Penal: parte geral. Porto Alegre: Sergio Antonio Fabris, 1976, p. 103. Sobre o erro de proibição direito, afirma Tereza Serra que: "este erro concorre quando o agente não conhece ou, conhecendo-a, considera-a revogada ou interpreta-a erradamente - a norma proibitiva que concerne directamente ao facto, tomando o seu comportamento como permitido e aprovado pelo Direito" SERRA, Tereza. Problemática do erro sobre a ilicitude. Coimbra: Almedina, 1991, p. 69. 
é definida através do desconhecimento da lei, mas sim através do desconhecimento da norma proibitiva, que impede a valoração negativa do comportamento. Por conseguinte, no erro de proibição direito, desconhece-se a antinormatividade." 41

O erro de proibição direto incide, assim, sobre a existência, a validade da norma proibitiva.

Segundo Juarez Cirino dos Santos, “o erro de proibição direto pode incidir sobre a existência, sobre a validade e sobre o significado da lei penal" 42 .

Juarez Cirino dos Santos adota uma postura bastante peculiar ao classificar as hipóteses de erro de proibição direito, pois em vez de adotar como objeto a norma proibitiva, referido autor adota como objeto a própria lei penal, com a finalidade nítida de afastar o inadequado princípio de que o conhecimento da lei penal se presume.

${ }^{41}$ BRANDÃO, Cláudio. Bem jurídico e norma penal: a função da antinormatividade na teoria do crime. DELICTAE: Revista de Estudos Interdisciplinares sobre o Delito, [S.1.], v. 3, n. 4, p. 07-45, jul. 2018. ISSN 2526-5180. Disponível em: <http://www.delictae.com.br/index.php/revista/article/view/61>. doi: https://doi.org/10.24861/2526-5180.v3i4.61, p. 28.

${ }^{42}$ SANTOS, Juarez Cirino dos. A moderna teoria do fato punível. Curitiba: Fórum, 2004, p. 243. 
Entretanto, não se concorda com o posicionamento do autor, em afirmar que o erro sobre o significado da lei penal é hipótese de erro de proibição direito, aqui se adota a postura de que o erro de subsunção é hipótese de erro de tipo, como se verificará adiante.

O erro sobre a existência da norma proibitiva é a modalidade mais comum de erro de proibição, cuja incidência se encontra, via de regra, condicionada ao nível cultural do povo, ou seja, quanto menor o nível de escolarização, maior a frequência do erro.

Verificadas, assim, as parcelas da sociedade que incidem em erro com mais frequência, devem, as autoridades públicas, em vez de se preocuparem com a imputação de uma pena a alguém, reafirmando o vetusto e inconstitucional ${ }^{43}$ princípio de que todos devem conhecer a lei, sem analisar-se, ao menos, a consciência do injusto, adotar políticas públicas com o escopo de escolarizar referida parcela da população.

O erro sobre a validade da norma de proibição não se refere, propriamente, ao conhecimento da norma proibitiva, mas sim ao não reconhecimento de sua validade, por entender-se que referida norma proibitiva contraria os direitos fundamentais, o

${ }^{43}$ Inconstitucional, visto que o princípio do error ius nocet, previsto em lei ordinária, artigo 21 primeira parte, do Código Penal, vai de encontro com os princípios da legalidade e culpabilidade, tutelados pela Constituição Federal em seu artigo 5o, incisos XXXIX (legalidade) e XLVI (culpabilidade). 
princípio da legalidade ou outros princípios jurídicos superiores. Ressalta Cirino dos Santos que:

[...] a invalidade da lei deve se basear em fundamentos reconhecidos pelo ordenamento jurídico, e não em convicções pessoais, políticas ou religiosas do autor (o estudante de direito, convencido por opiniões doutrinárias ou manifestações da jurisprudência da invalidade da incriminação da posse de drogas para uso próprio, porque fere a garantia constitucional da privacidade e, também, o princípio da legalidade, por ausência de lesão a bem jurídico - não constitui ofensa à saúde pública, e o perigo de autolesão é impunível -, não pode ser reprovado pelo consumo de cannabis sativa na esfera privada da vida) ${ }^{44}$.

Por último, o erro sobre o significado da norma proibitiva, também denominado erro de subsunção, da mesma forma que o erro sobre a validade da norma de proibição, também

${ }^{44}$ SANTOS, Juarez Cirino dos. A moderna teoria do fato punível. Curitiba: Fórum, 2004, p. 244. 
supõe o conhecimento da proibição, mas incide sobre a interpretação do tipo penal, frequente nos tipos do direito penal econômico, constituídos, via de regra, por elementos normativos especiais da ilicitude.

No presente artigo, adotou-se o posicionamento de que o erro sobre os elementos normativos do tipo e sobre os elementos jurídicos normativos da ilicitude ${ }^{45}$ são hipóteses de erro de tipo, pois referidos elementos normativos se encontram presentes no tipo penal.

De se registrar que o assunto do erro sobre os elementos jurídicos normativos da ilicitude não é pacífico na doutrina, que se divide em duas: os partidários de que referida modalidade de erro constitui hipótese de erro de tipo, pois nele se localiza, devendo o dolo abrangê-los. E os que acreditam ser hipótese de erro de proibição, porque, afinal, referidos elementos tratam da antijuridicidade da conduta.

45 "Cumpre destacar, desde logo, que os elementos normativos do tipo não se confundem com os elementos jurídicos normativos da ilicitude. Enquanto aqueles são elementos constitutivos do tipo penal, estes, embora integrem a descrição do crime, referem-se à ilicitude e, assim sendo, constituem elementos sui generis do fato típico, na medida em que são, ao mesmo tempo, caracterizadores da ilicitude. Esses 'elementos normativos especiais da ilicitude', normalmente, são representados por expressões como 'indevidamente', 'injustamente', 'sem justa causa', 'sem licença da autoridade' etc. 
Ora, se o erro de tipo é a falta de conhecimento ou a falsa compreensão dos elementos - quer fáticos, quer normativos - previstos no tipo penal, então o erro sobre os elementos normativos especiais da ilicitude é hipótese de erro de tipo.

No tocante aos elementos normativos do tipo, uma crítica se faz pertinente, tendo em vista a complexidade crescente dos tipos penais.

Os membros do Congresso Nacional devem adotar a técnica de elaborar tipos penais cada vez mais claros, evitando a utilização de elementos normativos. Todavia não parece ser essa a técnica utilizada pelo legislador pátrio (e estrangeiro, registrese), pois, hodiernamente, vive-se não só um momento de edição desenfreada de leis penais, mas também da complexificação dos conteúdos destes diplomas legislativos. Isso faz com que se dê margem as mais diversas interpretações, fazendo com que o cidadão desconheça o significado da própria lei penal.

\subsection{Erro de proibição indireto}

O erro de proibição indireto, também conhecido por erro de permissão, configura-se quando o agente, mesmo conhecendo a proibição, acredita que sua conduta está regulada por uma causa excludente de ilicitude.

$\mathrm{O}$ agente erra quanto à existência de uma causa de justificação inexistente, ou se equivoca quanto aos limites de uma causa de justificação existente. Segundo Cirino dos Santos, 
O erro de permissão, ou de proibição indireto, tem por objeto a existência de uma causa de justificação inexistente, ou os limites jurídicos de uma causa de justificação não reconhecida na lei (castigar crianças alheias por grosserias, no suposto exercício de direito de correção); no erro sobre limites jurídicos de justificação existente, o autor atribui à justificação limites diferentes dos atribuídos pelo legislador - nesse aspecto, corresponde ao erro sobre a existência de justificação inexistente: ao realizar prisão em flagrante, o cidadão comum produz lesão corporal grave na pessoa do preso $^{46}$.

O erro de permissão segue as regras do erro de proibição direto, não excluído, portanto, a culpabilidade, quando o erro for evitável ${ }^{47}$.

No erro de tipo permissivo, diferentemente, a representação realizada pelo autor coincide com a representação

${ }^{46}$ SANTOS, Juarez Cirino dos. A moderna teoria do fato punível. Curitiba: Fórum, 2004, p. 244.

47 WESSELS, Johannes. Direito Penal: parte geral. Porto Alegre: Sergio Antonio Fabris, 1976, p. 106. 
do legislador, entretanto o agente erra quanto à verdade do fato, ou seja, o agente erra quanto à existência de circunstância fática, que se existisse, tornaria legítima a sua ação.

No erro de proibição indireto, o agente entende corretamente o fato, mas a sua representação do direito e do injusto contradizem a do legislador, visto que o agente cria uma descriminante putativa inexistente ou erra quanto aos seus limites ${ }^{48}$.

São exemplos de erro quanto à existência de uma causa de justificação: o agente que castiga corporalmente os filhos de outrem, por travessuras, pensando existir uma causa excludente de ilicitude para tanto, ou quando sabota recursos militares supondo existir um direito de promover a paz mundial lhe autorizando para tanto ${ }^{49}$.

No erro quanto aos limites de uma causa de justificação existente, o agente atribui à excludente de ilicitude limites distintos dos atribuídos pelo legislador. Segundo Roxin, “[...] quien fija los límites de una causa de justificación de manera distinta que el legislador también supone en esa medida una causa de justificación que no existe." 50

48 WESSELS, Johannes. Direito Penal: parte geral. Porto Alegre: Sergio Antonio Fabris, 1976, p. 106.

${ }^{49}$ ROXIN, Claus. Derecho penal: parte general. Madrid: Civitas, 1997, p. 871.

${ }^{50}$ ROXIN, Claus. Derecho penal: parte general. Madrid: Civitas, 1997, p. 872. 


\subsection{Erro de proibição mandamental}

No erro de proibição direto, o agente compreende mal ou não compreende uma norma proibitiva. Já no erro de proibição mandamental, a relação de compreensão será feita com relação a uma norma imperativa, visto que, no direito penal, não há apenas normas proibitivas, onde a conduta criminosa se manifesta através de uma ação (conduta comissiva), mas também existem normas impositivas, ou seja, imperativas (normas de mandamento), onde a conduta criminosa se manifesta por meio de uma omissão (conduta negativa).

O erro de mandamento poderá acontecer em qualquer crime omissivo, próprio ou impróprio. A omissão própria é o deixar de agir. Já a omissão imprópria é quando há a violação de uma norma proibitiva por omissão. A omissão imprópria também é conhecida por comissão por omissão.

Observe a seguinte situação hipotética sobre erro mandamental: Diante de determinado acidente com veículo automotor, A percebe que há pessoas feridas dentro dos veículos. Ao pensar que é de obrigação dos policiais rodoviários e do corpo de bombeiros socorrer as pessoas, A deixa de prestar socorro. A incide, assim, em erro de proibição, quanto a uma norma imperativa (erro de proibição mandamental), pois não presta socorro, quando deveria, por desconhecimento da ilicitude de determinada conduta. 
Um exemplo de erro de proibição mandamental, quanto à posição do garantidor, dá-se na seguinte situação: $\mathrm{A}$ pede a sua irmã $\mathrm{B}$, para que tome conta de sua filha $\mathrm{C}$. B aceita o encargo, por conta da insistência de sua irmã, colocando-se, assim, na posição de garante, segundo o que dispõe o parágrafo 2o, alínea $b$, do artigo 13 do Código Penal brasileiro. Ocorre que C toma uma substância que lhe causa lesão corporal e grita por ajuda. $B$, entretanto, abstém-se de socorrer $C$, porque também está presente na casa a prima de $\mathrm{A}$, e tem convicção que já está tendo trabalho demais em cuidar da filha de A.

\section{Erro quanto à norma penal em branco}

No tocante às leis penais em branco ${ }^{51}$, surge o problema de como se tratar o erro sobre a norma complementar. Com base na dicotomia tradicional, erro de fato-erro de direito, o problema era resolvido a partir da natureza da norma complementar. Se a norma complementar fosse de direito penal, não se excluía a responsabilidade, por se tratar de um erro de direito. Entretanto, se a norma complementar fosse de natureza extra-penal, excluía-se o dolo, afastando a responsabilidade do agente.

${ }^{51}$ A lei penal em branco pode ser conceituada como aquela em que a descrição da conduta punível se mostra incompleta, lacunosa, necessitando de outro dispositivo legal para a sua integração ou complementação. 
Atualmente, deve-se partir de outras premissas. Segundo Jescheck, o tratamento da norma complementar deve seguir as regras gerais da teoria do erro, ou seja, o erro acerca de um elemento objetivo da norma que complementa a lei penal em branco será um erro de tipo, enquanto que o erro sobre a existência daquela norma será um erro de proibição ${ }^{52}$.

Sobre o tratamento do erro quanto à norma penal em branco, afirma Roxin que

Especialmente difícil y discutida resulta la delimitación del error de tipo y el de prohibición en las leyes penales en blanco. Estas son tipos que sólo contienen una norma sancionadora, pero que dejan sin embargo su integración a otras leyes, reglamentos o incluso actos administrativos. Se encuentran con mucha frecuencia en el Derecho penal accesorio, pero no escasean tampoco en el StGB, p.ej. en el $\S 315$ a I n.o 2, según el cual será castigado quien como conductor o piloto "infrinja los preceptos jurídicos del tráfico ferroviario, funicular, marítimo o aéreo"

52 JESCHECK, Hans-Heinrich, WEIGEND, Thomas. Tratado de derecho penal: parte general. Granada: Comares, 2002, p. 331. 
mediante una conducta gravemente contraria a deber y produzca con ello peligros concretos. BGHSt 6, 40, habla de una ley penal en blanco cuando el tipo y la conminación de pena "están separados de modo tal que la integración de la conminación de pena mediante el correspondiente supuesto de hecho se lleva a cabo independientemente por otra instancia y en otro momento".

En tales casos un error sobre la existencia de la norma integradora o la suposición de una causa de justificación inexistente es un error de prohibición, mientras que el error sobre circunstancias del hecho de la norma integradora excluye el dolo ${ }^{53}$.

Nesse sentido, segundo os postulados da dicotomia finalista, erro de tipo-erro de proibição, parece claro que, quando o erro recair sobre a existência da norma complementar, será tratado como erro de proibição, enquanto que se o agente erra quanto a um elemento objetivo da norma complementar, será

${ }^{53}$ ROXIN, Claus. Derecho penal: parte general. Madrid: Civitas, 1997, p. 465-466. 
tratado como erro de tipo. Para o caso brasileiro, é perfeitamente cabível o posicionamento de Roxin e Jescheck.

\section{CONCLUSÃO}

O erro de proibição é a falta de conhecimento acerca da ilicitude de um fato ou a sua falsa compreensão. $O$ erro de proibição é, portanto, o erro sobre a antijuridicidade do fato.

O erro de proibição se diferencia do erro de tipo, porque nesse último o agente crê que está a realizar uma ação diversa da que pratica. Ainda, deve-se ressaltar que o erro de tipo exclui diretamente o injusto (ao menos o injusto doloso, visto que, nos crimes que existem a previsão na modalidade culposa, o agente poderá ser responsabilizado se não observou o dever jurídico de cuidado), enquanto que o erro de proibição eliminará a culpabilidade quando inevitável, sem ter relação com a tipicidade, de modo que se o erro de proibição for vencível não poderá, jamais, gerar uma tipicidade culposa. Mas o erro de tipo vencível pode dar lugar a uma tipicidade culposa, se houver, repita-se, previsão legal. $O$ erro de proibição somente afeta a reprovabilidade do injusto. Assim, o único efeito de um erro de proibição vencível é produzir uma menor reprovação.

Se o erro de proibição exclui a culpabilidade, então se diz que o erro de proibição é escusável, ou invencível. Não há um critério fixo para se determinar a escusabilidade do erro de proibição, visto que em cada caso concreto cabe ao juiz decidir se 
o sujeito possuía ou não consciência de ilicitude e, caso o autor não tivesse referida consciência de ilicitude, se era possível adquiri-la (daí a consciência de ilicitude não ser atual, mas sim potencial).

Diferentemente do erro de proibição escusável (invencível), o erro de proibição inescusável (vencível) não elimina a responsabilidade do agente, ou seja, a reprovação de sua conduta permanece íntegra.

O erro de proibição pode ser, ainda, direto, indireto e mandamental. Há erro de proibição direto quando o agente não compreende uma norma proibitiva ou faz uma má-interpretação sobre o seu respeito. Norma proibitiva não está aqui empregada no sentido de lei, mas de antijuridicidade.

O erro de proibição indireto, também conhecido por erro de permissão, configura-se quando o agente, mesmo conhecendo a proibição, acredita que sua conduta está regulada por uma causa excludente de ilicitude. $\mathrm{O}$ agente erra quanto à existência de uma causa de justificação inexistente, ou erra quanto aos limites de uma causa de justificação existente.

No erro de proibição direto, o agente compreende mal ou não compreende uma norma proibitiva, enquanto que no erro de proibição mandamental a relação de compreensão será feita com relação a uma norma imperativa.

REFERENNCIAS 
ASÚA, Luis Jiménez. La ley e el delito: curso de dogmática penal. Caracas: Adreas Bello, 1945

BALESTRA, Carlos Fontán. El elemento subjetivo del delito. Buenos Aires: Desalma, 1957, p. 142-143). Ainda no mesmo sentido Edgard Magalhães Noronha (Direito penal: introdução e parte geral. São Paulo: Saraiva, 1999

BARREALES, María A. Trapero. El error en las Causas de Justificación. Valencia: Tirant lo blanch, 2004

BITENCOURT. Cezar Roberto. Erro de tipo e erro de proibição: uma análise comparativa. São Paulo: Saraiva, 2003

BRANDÃO, Cláudio. Bem jurídico e norma penal: A função da antinormatividade na teoria do crime. DELICTAE: Revista de Estudos Interdisciplinares sobre o Delito, v. 3, n. 4, p. 07-45, 2018.

Disponível

em:

<http://www.delictae.com.br/index.php/revista/article/view/61

>. doi: https://doi.org/10.24861/2526-5180.v3i4.61

BRANDÃO, Cláudio. Culpabilidade: sua visão na dogmática penal e nos tribunais brasileiros. Revista portuguesa de ciência criminal. Ano 15. N.2. Coimbra: Coimbra editora. 2005

BRANDÃO, Claudio; HOMEM, Pedro Barbas. Do direito natural aos direitos humanos. Coimbra:Almedina. 2015.

BRANDÃO, Claudio. Inconsciência de antijuridicidade - sua visão na dogmática penal e nos tribunais brasileiros. Revista da 
Faculdade de Direito da Universidade de Lisboa. Vol XLI, N.1, Coimbra: Coimbra Editora. 2000.

BRANDÃO, Claudio. The roots of human rights: the epistemological turn provoked by Francisco de Vitória. HUMANITIES AND RIGHTS GLOBAL NETWORK JOURNAL. Vol. 1. I.1, 7-20. 2019. https://doi.org/10.24861/2675-1038.v1i1.9

BRANDÃO, Cláudio. Teoria jurídica do crime. Rio de Janeiro: Forense, 2002

BRANDÃO, Claudio. Tipicidade penal: dos elementos da dogmática ao giro conceitual do método entimemático. Coimbra:Almedina. 2012.

BRANDÃO, Claudio. Tobias Barreto e pena criminal. Revista de Estudos Criminais. Ano XI, N.50, São Paulo:Síntese. 2013

CÓRDOBA RODA, Juan. Una nueva concepción de delito: la doctrina finalística. Barcelona: Ariel, 1977, p. 23

ESPINAR, José M. Zugaldía; ALONSO, Esteban J. Pérez. Derecho penal: parte general. Valencia: Tirant lo blanch, 2002 JESCHECK, Hans-Heinrich, WEIGEND, Thomas. Tratado de derecho penal: parte general. Granada: Comares, 2002.

KAUFMANN, A. e HASSEMER, W. Introdução à Filosofia do Direito e à Teoria do Direito Contemporâneas. Lisboa: Fundação Calouste Gulbenkian, 2002

MEZGER, Edmund. Derecho penal: parte general, libro de estudios. Buenos Aires: Editorial Bibliográfica Argentina, 1955 MEZGER, Edmund. Tratado de derecho penal. Tomo II. Madrid: Revista de Derecho Privado, 1949, 
MUNHOZ NETTO, Alcides. A ignorância da antijuridicidade em matéria penal. Rio de Janeiro: Forense, 1978

NORONHA, Edgard Magalhães .Direito penal: introdução e parte geral. São Paulo: Saraiva, 1999

PLATÃO. As leis, ou da legislação e epinomis. São Paulo: Edipro, 1999

ROXIN, Claus. Derecho penal: parte general. Madrid: Civitas, 1997

SANTOS, Juarez Cirino dos. A moderna teoria do fato punível. Curitiba: Fórum, 2004

SERRA, Tereza. Problemática do erro sobre a ilicitude. Coimbra: Almedina, 1991

STRATENWERTH, Günter. Derecho penal: parte geral. Caracas: Editoriales de Derecho Reunidas, 1982

TOLEDO, Francisco de Assis. Princípios básicos de direito penal.

São Paulo: Saraiva, 1982

WELZEL, Hans. Derecho penal alemán: parte general. Santiago: Editorial Juridica de Chile, 1997

WESSELS, Johannes. Direito Penal: parte geral. Porto Alegre: Sergio Antonio Fabris, 1976

ZAFFARONI, Raúl Eugenio; Alejandro Slokar; e Alejandro Alagia. Manual de derecho penal: parte general. Buenos Aires: Editar, 2006. 